\title{
Balanced diets - the secret to adequate sustainability for everyone
}

\section{Dietas equilibradas - o segredo para uma adequada sustentabilidade de todos nós}

\author{
Augusto Manuel Correia \\ CENTROP/Instituto Superior de Agronomia, Universidade de Lisboa \\ Tapada da Ajuda \\ Email: correiagmanuel@gmail.com
}

\begin{abstract}
Until the industrial revolution, agricultural systems were based mainly on the exploitation of natural resources and diets were almost always diversified. With the auspices of modern agriculture and the population growth, the answer to food production concentrated mainly in the selection of some crops that better corresponded to the quantitative needs, observing, in general, a clear loss in the diversity of diets and their nutritional richness.

The fact that the strategies used for the development of the more disadvantaged people were for a long time sectorspecific delayed the due importance to the need of having a holistic approach.

This approach, for which many authors have received attention, is highlighted in the text. Strategies are sustained that can lead to cross approaches from the different sectors (agriculture, health and education, for example) that can contribute to a more equitable world, based on sustainable agricultural and balanced nutritional systems that correspond to the real needs of the population.
\end{abstract}

Keywords: Food security, nutrition, development, new challenges

\footnotetext{
Resumo

Até à revolução industrial, os sistemas agrícolas baseavam-se fundamentalmente na exploração dos recursos naturais e em dietas quase sempre diversificadas. Com os auspícios da agricultura moderna e com o aumento demográfico registado, a resposta para a produção de alimentos concentrou-se essencialmente na selecção de algumas culturas que melhor correspondiam às necessidades quantitativas observando-se, na generalidade, uma perda evidente na diversidade das dietas e do seu poder nutricional.

$\mathrm{O}$ facto das estratégias para o desenvolvimento dos mais desfavorecidos, durante muito tempo, se fazerem por sector, atrasou o facto de se dar a devida importância à necessidade da sua abordagem holística.

Essa abordagem, para que muitos autores vêm chamado a atenção, é realçada no texto defendendo-se estratégias que possam conduzir a estratégias cruzadas dos diferentes sectores (agricultura, saúde e educação, por exemplo) que possam contribuir para um mundo mais equitativo e assente em sistemas agrícolas sustentáveis e sistemas nutricionais equilibrados e que correspondam às reais necessidades da população.
}

Palavras-chave: Segurança alimentar, nutrição, desenvolvimento, novos desafios 
Forty years ago, when I started working with small farmers in Africa - regardless of what I have learned from them - I was soon convinced that their future would pass forcibly by the capacity they had to increase their food/crop production. After all this time, their productivity remains virtually the same despite many theories on the subject and the millions of euros spent on their support. The victories obtained in the field are far from corresponding to what was expected. None of these evidences could be used to certify my previous assumption, but this issue would take us to another kind of discussion and it's better to be back then to the subject of diets.

The industrial revolution changed the traditional agricultural methods of cultivation, exclusively based on the exploitation of natural resources, and transformed it in an economic activity. Initially, that transformation just extended to the richest regions i.e. where the industrial revolution began to result in benefits. Years later, the green revolution appeared to try to boost agriculture in the least developed countries, but of course with a strategy focused on availability of calories by increasing the areas devoted to cereals, mainly rice, maize, and wheat, which contributed directly to a deficient diet in terms of micronutrients in many developing countries ${ }^{1}$. From over 80,000 species of plant available to humanity, only those three have managed to contribute to the growing needs of energy and protein, which has led the nutritionists to insist on the need to evolve into multicultural systems i.e., more varied, to obtain adequate dietary diversification.

Being a professional on tropical agronomy and development, in 2002 I was fortunate enough in reading a book edited by IFPRI "The unfinished agenda" which, in my opinion, is the best technical book on this subject that I have read. When compared with others that I had access to, it does not bring any promises of miracles for the development but reminds us who is losing and what still remains to be done in a variety of areas to inhabit a more fair world without trying to point blame or guilt. Although the book was awarded with the "2001 World Food Prize", I've seen few references to it in academic bibliography. ${ }^{2}$ Much to my surprise, on page16, the authors say that among the determinants that contributed to improve the diet of children between 1970 and 1995, the availability of food only had contributed with $26.1 \%$, the improvement of health care with $19.3 \%$, the status of women with $11.6 \%$ and the education of women with $43 \%$. Those authors have referred that "micronutrient deficiency remains widespread in the poorest countries. About of 2000 million people would present serious problems of iron deficiency, more than two million of iodine and more than 250 million of vitamin A" (p. 9).
Quando há quarenta anos comecei a trabalhar com os pequenos agricultores em África, independentemente do muito que me ensinaram, fiquei logo convencido de que o futuro deles passaria forçosamente pela capacidade que houvesse para um incremento das suas produções. Não abonará muito a meu favor saber que as suas produtividades continuam praticamente na mesma e independentemente da conversa teórica sobre o assunto e dos milhões de euros gastos no seu apoio, as vitórias obtidas nem de longe corresponderão àquilo que se estaria à espera. Mas isso levar-nos-ia para outro tipo de assunto. Voltemos então às dietas.

A revolução industrial veio tirar a agricultura da sua forma até então habitual, exclusivamente baseada na exploração dos recursos naturais, para a transformar, cada vez mais, numa actividade económica. Inicialmente, aquela transformação apenas se estendeu pelas regiões mais ricas ou seja, onde a revolução industrial começou a dar os seus resultados. Anos mais tarde, a revolução verde apareceu para tentar dinamizar a agricultura nos países menos desenvolvidos mas naturalmente com uma estratégia focada na disponibilidade de calorias pelo incremento das áreas dedicadas aos cereais e principalmente ao arroz, milho e trigo o que contribui logo para uma deficiente dieta em termos de micronutrientes em muitos países em desenvolvimento ${ }^{1}$. De mais de 80.000 espécies de plantas disponíveis para a humanidade, apenas aquelas três têm conseguido contribuir para as necessidades crescente de energia e proteína o que tem levado os nutricionistas a insistir na necessidade de se evoluir para sistemas de multiculturas isto é, mais diversificados, para a obtenção de uma adequada diversificação da dieta.

Sendo um homem da agronomia tropical e do desenvolvimento, em 2002, tive a sorte de ler um livro editado pelo IFPRI "The unfinished agenda" que, na minha opinião será o livro técnico que mais me marcou pois, ao contrário da maioria dos que tenho tido acesso, não trás nenhuma promessa de milagre para o desenvolvimentos dos mais carenciados mas, em vez disso lembra apenas, a quem anda distraído, aquilo que ainda falta fazer, nas mais variadíssimas áreas para habitarmos um mundo mais justo sem tentar apontar culpas ou culpados. Embora tenha ganho o "2001 World Food Prise" poucas referências tenho visto em relação a ele na bibliografia ${ }^{2}$. Para grande surpresa minha, na pág. 16 entre as determinantes que tinham contribuído para melhorar a dieta alimentar das crianças ente 1970 e 1995, a disponibilidade de alimentos apenas tinha contribuído com $26,1 \%$, a melhoria dos cuidados de saúde com $19,3 \%$, o estatuto da mulher com $11,6 \%$ e a educação das mulheres com $43 \%$. Aqueles autores referiam já que"a deficiência em micronutrientes mantém-se ge- 
And added, "little attention has been given to other so-called" forgotten "micronutrients such as zinc, riboflavin, calcium and the failure to have a clear idea of the consequences caused by these same shortcomings though, generally, have a strong impact on mortality, on morbidity, cognitive development in the workforce and in the reproductive capacity of course with a global negative impact in economic development thus creating the recognized vicious cycle between poverty and malnutrition" (p. 9) Unfortunately, fifteen years after the book's publication, the considerations today will be more or less the same.

It seems that the major challenge of humanity, in spite of everything that has been done, will continue to be the ability to feed a growing population, reaching up to 9 billion people by 2050 in a proper manner (quantitative and qualitative) and based on sustainable systems. It's really an extraordinary challenge that, honestly, I hope we can obtain the appropriate responses for, because, looking at the strategies that are possible today to foresee, they are still divergent. Above all, on the basis of the experience acquired throughout life, we continue with a very different practice between what actually happens in the countryside and the speech that we hear in different fora, in debate around the world, these same strategies.

Based upon all of this is born in me the belief that issues of rural development in less developed regions should deserve a more holistic approach, combining across the various knowledges and opportunities. Beginning with the integration of different projects on agriculture, and health strategies to which can easily be joined the education, to me seems appropriate. This approach can be and without doubt is a different strategy from that which has been used for the fight against poverty and to promote development until now.

Produce more. Yes, but what? As we all know, there is an increasingly serious interest in reducing mortality of children under 5 years of age. I have little doubt that, with appropriate diagnostics, not only on these children but also the older, we can easily obtain data on the nutritional status of the youth and to identify which elements are necessary to evolve towards more balanced diets. This intersection of information with the agricultural sector, public or private, can lead to the development of public policies that promote the availability of appropriate foods for more balanced diets. Today we increasingly hear about the production of fortified foods but, even for these, the question is the same, what kind of fortification we need in order to achieve the desired results.

Of course, I'm not forgetting that the construction of these combinations is, by various constraints, difficult neralizada nos paises mais pobres. Cerca de 2000 milhões de pessoas apresentariam problemas graves por deficiência de ferro, mais do que dois milhões em iodo e mais de que 250 milhões em vitamina A" pag. 9. E acrescentavam, "pouca atenção tem sido dada a outros micronutrientes denominados por "esquecidos" como zinco, riboflavina, cálcio e ainda ao facto de não se ter uma ideia clara das consequências originadas por essas mesmas carências sabendo-se, genericamente, têm um forte impacto na mortalidade, na morbilidade, no desenvolvimento cognitivo, na força de trabalho e na capacidade reprodutiva naturalmente com um impacto global negativo no desenvolvimento económico gerando assim o reconhecido ciclo vicioso entre a pobreza e a má nutrição” (pag. 9). Quinze anos depois, a actualidade daquele documento, não pode deixar de ser confrangedora para todos os que ligam com estes assuntos. Parece assim que o grande desafio da humanidade, apesar de tudo o que foi feito ou do que se diz que fez, continuará a ser, o de conseguir alimentar uma população que evoluirá até aos 9 mil milhões de pessoas até 2050 de forma adequada (quantitativa e qualitativamente) e com base em sistemas sustentáveis. É realmente um desafio extraordinário que, honestamente, espero que consigamos obter as respostas adequadas pois, olhando para as estratégias que são possíveis hoje descortinar, elas ainda são divergentes e sobretudo, com base na experiência adquirida ao longo da vida, continuamos com uma prática bem diferente entre o que realmente acontece no mundo rural e o discurso que vamos ouvindo nos fora que, com cada vez mais frequência, debatem pelo mundo fora, essas mesmas estratégias.

É com base em tudo isto, que nasce em mim a convicção de que, as questões do desenvolvimento rural nas regiões menos desenvolvidas, deveriam merecer uma abordagem mais holística conjugando transversalmente os diversos saberes e oportunidades. Começar pelo entrosamento dos projectos ou estratégias da agricultura e da saúde a que facilmente se poderá juntar a educação, parece-me adequado e sem dúvidas uma estratégia diferente daquela que se tem utilizado para o combate à pobreza e naturalmente ao desenvolvimento.

Produzir mais, sim, mas o quê? Como todos acompanhamos, há um interesse cada vez mais sério na redução da mortalidade das crianças com menos de 5 anos. Tenho poucas dúvidas que, com diagnósticos adequados, não só a estas crianças como às mais velhas, poderemos facilmente obter dados sobre o estado de desnutrição das camadas jovens e identificar quais os elementos necessários para se evoluir na direcção de dietas mais equilibradas. Este cruzamento de informação com o sector agrícola, público ou privado, pode levar à elaboração de políticas públicas que favoreçam a disponi- 
or very difficult to make happen. In this sense, I think on the important role the international cooperation to the development which could, instead of just promoting technology transfer (at the expense of slogans like "innovate to develop"), empower countries to identify what is important to them - in terms of their real agricultural and food security problems and how to respond efficiently to the needs of countries. Of course, those problems and answers will change according to the new challenges that will always appear.

How can we try to respond in a balanced way to the constitution of diets better suited to actual needs?

a) As mentioned, the prior diagnostic of the nutritional status, although not essential, will be a decisive tool for the design of a proper diet and naturally with greater importance to the school-age population in an attempt to respond to the need of cognitive development that all human beings should have;

b) Preservation of biodiversity of agricultural systems. Although the agriculture evolution has been towards monoculture (and within these, very few), the polyculture, which even some small farmers can do, can be the key to genetic crop recovery that may still be essential to mankind. Today, some even argue that biodiversity can achieve international economic importance as that currently is given to the "carbon trading". The interaction of biodiversity with sustainable agricultural systems is increasingly apparent to its preservation and sustainability ${ }^{3}$.

c) Once the gaps of the essential elements to a balanced diet are identified, and admitting that the diets resulting from the self-production or purchased food are not always balanced, we can still pursue strategies like the formulation of crackers for distribution to children in addition to their food or promoting multimixtures which, for their compositions ${ }^{4}$, can help to bridge some of the shortcomings referenced, and can also bring a commercial incentive and vibrant agricultural sector through increased demand generated in the products used for the different formulations. These are just two examples among many which are appearing but whose implementation should be looked at seriously in formulating appropriate public policies and to the development of the poorest populations;

d) Education and training to various levels and ages, with a focus on adult women and teachers, which typically raise children and decide what to eat, it seems to be an important evidence that we cannot fail to point out.

It seems clear that an approach based on vertical interventions is not applicable anymore to solve the world's problems and won't give us today the appropriate re- bilidade de alimentos mais adequados para dietas mais equilibradas. Hoje cada vez mais se fala na produção de alimentos fortificados mas, até para estes, a questão é, fortificados em quê? Para que se possam atingir os resultados desejados.

Naturalmente que não me estou a esquecer, que a construção destas combinações é, pelos mais variados constrangimentos, difícil ou muito difícil de acontecer. É aqui que deve entrar a cooperação internacional que, em vez de apenas promover a transferência de tenologia muitas vezes à custa de slogans como "inovar para desenvolver" se esquece do essencial que é o de capacitar os países naquilo que lhes é importante - a identificação dos reais problemas e responder eficientemente às necessidades dos países que, naturalmente, se alteram facilmente de acordo aos novos desafios que sempre vão aparecendo.

Como é que podemos tentar responder de forma equilibrada para a constituição de dietas mais adequadas às reais necessidades? Algumas pistas:

a) Como referimos, o prévio diagnóstico do estado nutricional, embora não essencial, será uma ferramenta decisiva para o desenho de uma dieta adequada e naturalmente com maior importância para a população em idade escolar na tentativa de se conseguir responder à necessidade da evolução cognitiva que todos os seres humanos deverão ter;

b) Preservação da biodiversidade dos sistemas agrícolas. Embora a evolução da agricultura tenha sido no sentido da monocultura (e dentro destas, de muito poucas), a policultura, que ainda alguns pequenos agricultores conseguem fazer, pode ser a chave para a recuperação genética de culturas que ainda podem ser essenciais para a humanidade. Hoje, há mesmo quem defenda que a biodiversidade poderá atingir uma importância económica internacional como aquela que actualmente se dá ao "comércio do carbono". A interacção da biodiversidade com a sustentabilidade nos sistemas agrícolas é cada vez mais evidente para a sua preservação e sustentabilidade ${ }^{3}$;

c) Identificadas que estejam as lacunas dos elementos essenciais para uma alimentação equilibrada, e admitindo que nem sempre as dietas provenientes da produção própria ou de compra de alimentos, consigam ser equilibradas, podemos ainda recorrer a estratégias como a formulação de bolachas, para a distribuição às crianças como complemento para a sua alimentação ou a promoção de uma multimistura ${ }^{4}$, as quais, pelas suas composições, além de poderem ajudar a colmatar algumas das carências entretanto referenciadas, podem também trazer um incentivo comercial e uma dinamização ao sector agrícola através de uma maior procura gerada nos produtos utilizados para as diferente formulações. 
sponses to the development of an adequate food supply. Beyond the quantities required, it will be increasingly important that dietary patterns are healthy and based on sustainable cultural systems.

We all know about this issue... the only thing missing is doing the right thing.

\section{Conflict of interests}

The authors declare that there are no financial and/or personal relationships that could be viewed as presenting a potential conflict of interests.
Estes são apenas dois exemplos entre os inúmeros que vão aparecendo mas, cuja implementação deve ser olhada seriamente na formulação e políticas públicas adequadas ao desenvolvimento dos mais carenciados. d) A educação e a capacitação aos mais variados níveis e idades, com uma incidência importante sobre as mulheres adultas e professoras, que normalmente educam e decidem o que comer, parece ser uma importante evidência que não podemos deixar de salientar.

Parece evidente que uma abordagem dos problemas do mundo sobre um prisma vertical não nos dará hoje as respostas adequadas ao desenvolvimento e muito menos, uma adequada alimentação. Para além das quantidades necessárias, será cada vez mais importante que os padrões alimentares sejam saudáveis e que se baseiem em sistemas culturais sustentáveis.

Já todos sabemos disto.....só falta mesmo é fazer

\section{Conflito de Interesses}

Os autores declaram não existir qualquer relação pessoal ou financeira que possa ser entendida como representando um potencial conflito de interesses. 


\section{References/ Referências}

1. Fanzo F, Hunter D, Borelli T, Mattei F. Eds. Diversifying Food and Diets - using agriculture biodiversity to improve nutrition and health. Routledge. London; 2013.

2. Pinstrup-Andersen P, Pandya-Lorch R. Eds. The Unfinished Agenda Perspectives on Overcoming Hunger, Poverty, and Environmental Degradation. International Food Policy Research Institute Washington, D.C. 2001.

3- Monteiro MF. A Questão da Segurança Alimentar nas Localidades de Ribeirão e Garça de Cima, Concelho de Ribeira Grande, Santo Antão - Cabo Verde. Tese de Mestrado em Agronomia Tropical,e Desenvolvimento Sustentável, ISA, Lisboa; 2012

4 - Neto F, Moldão-Martins M, Goulão LF. Caracterização do potencial de uma multimistura vegetal utilizada como suplemento alimentar na luta contra a insegurança nutricional em Moçambique. Tese de Mestrado em Engenharia Alimentar, ISA, Lisboa; 2014 